\title{
Development and Validation of Rapid, Sensitive RP-UPLC Method for Determination of Related Impurities in dexrabeprazole sodium
}

\author{
SANTOSH. T. KHADANGALE, ${ }^{1,2}$ VITTHAL. M. DHALAPE, ${ }^{1,2}$ and RAHUL. V. PINJARI ${ }^{\text {* }}$ \\ ${ }^{1}$ School of Chemical Sciences, Swami Ramanand Teerth Marathwada University, Nanded 431606, India. \\ ${ }^{2}$ Analytical Research Centre, Emcure Pharmaceuticals Limited, Hinjawadi, Pune 411057, India. \\ ${ }^{*}$ Corresponding author E-mail: rvp.chem @ srtmun.ac.in \\ http://dx.doi.org/10.13005/ojc/340526
}

(Received: August 13, 2018; Accepted: August 21, 2018)

\begin{abstract}
Dexrabeprazole sodium (DEX•Na) is an active pharmaceutical ingredient and used as proton pump inhibitor. A reverse phase (RP) ultra-performance liquid chromatographic (UPLC) method is developed for determination of related impurities in DEX $\mathrm{Na}$ and this method is validated using ICH guideline. This method was developed using BEH C18 $(2.1$ X $50 \mathrm{~mm}) 1.7 \mu \mathrm{m}$ column and gradient program for mobile phase. Mobile phase A contains $99 \%$ phosphate buffer of $\mathrm{pH} 7.0$ and $1 \%$ acetonitrile, where as mobile phase $B$ is the methanol and acetonitrile in 95:5 ratio. The $0.45 \mathrm{ml} / \mathrm{min}$. total flow rate, $3.0 \mu \mathrm{l}$ injection volume, $40^{\circ} \mathrm{C}$ column oven temperature and $284 \mathrm{~nm}$ detection wavelength are used with sampling rate of 5 points per second. The DEX•Na peak is well separated from its known and unknown impurities. The run time of the method is reduced to $10 \mathrm{~min}$. which is $\sim 11$ times smaller than methods reported in literature. The method is accurate and precise as well as linear in the range of LOQ to $150 \%$ level with respect to specification concentration limit of impurities. The stress conditions to DEX•Na revealed that drug is stable in alkaline medium, while it is sensitive to acidic and oxidative condition. The new method is sensitive, precise, accurate, and rapid; it also qualifies all the criteria of linearity, stability, as well as robustness.
\end{abstract}

Keywords: Dexrabeprazole sodium (DEX•Na), Rapid, Sensitive, Stability indicating, RP-UPLC, Lower level quantification and detection.

\section{INTRODUCTION}

Dexrabeprazole sodium $(\mathrm{DEX} \cdot \mathrm{Na})$ is $\mathrm{R}(+)$-isomer of Rabeprazole, (2-[[[4-(3-methoxy propoxy)-3-methyl-2pyridinyl]-methyl] sulfinyl] $1 \mathrm{H}$-benzimidazole)..$^{1,2,3}$ It belongs to a class of anti-secretory compounds that exhibit neither anti cholinergic nor histamine $\mathrm{H} 2$ receptor antagonist properties. However,DEX•Na suppresses gastric acid secretion by inhibiting the gastric $\mathrm{H}^{+} / \mathrm{K}^{+}$AT Pase at the secretory surface gastric parietal cells. ${ }^{4} \mathrm{DEX} \cdot \mathrm{Na}$ is thus a proton pump inhibitor and used to treat backward flow of acid from the stomach (gastroesophageal reflux disease), which causes heart-burn and possible injury of the oesophagus. ${ }^{5}$ It heals oesophagus and prevent

This is an 2 Open Access article licensed under a Creative Commons Attribution-Non Commercial-Share Alike 4.0 International License (https://creativecommons.org/licenses/by-nc-sa/4.0/), which permits unrestricted Non Commercial use, distribution and reproduction in any medium, provided the original work is properly cited. 
further damage. Several factors viz. the stability of the active ingredient, the manufacturing process, the environmental conditions (such as heat, light and moisture during storage) and chemical reactions (oxidation, reduction and hydrolysis) may affect the stability of a pharmaceutical product. ${ }^{6}$ Rabeprazole (RAB), conjugated acid of DEX•Na, has been reported as thermal, acidic and photo sensitive ${ }^{7,10}$ Several HPLC methods using UV and PDA detectors are reported for these related substances in
DEX $\bullet N a$ (see Table 1). ${ }^{11,12}$ The reverse phase (RP) HPLC method developed by Kumar et al., has 85 min. run time and LOQ for the related impurities between $0.020 \%$ to $0.036 \% .{ }^{11}$ In another article, the analytical method has achieved good sensitivity and relatively lower LOQ (0.005- $0.014 \%)$, however with longer run time (90 min.). ${ }^{12}$ Thus the present article reports the development and validation of the RP-UPLC method for related substances of DEX $\bullet \mathrm{Na}$ with higher sensitivity, lower levels of detection and quantification with considerably shorter run time

Table 1: Dexrabeprazole Sodium (DEX•NA) and its related impurities

\begin{tabular}{|c|c|c|c|}
\hline Name & Chemical Name & Chemical Structure & Type \\
\hline $\begin{array}{l}\text { Dexrabeprazole } \\
\text { Sodium } \\
(\mathrm{DEX} \cdot \mathrm{Na})\end{array}$ & $\begin{array}{l}\text { 1H-Benzimidazole, 2-[[[4- } \\
\text { (3-methoxypropoxy)-3- } \\
\text { methyl-2-pyridinyl]methyl] } \\
\text { sulfinyl]-, sodium salt. }\end{array}$ & & $\begin{array}{l}\text { Active } \\
\text { pharmaceutical } \\
\text { Ingredient. }\end{array}$ \\
\hline $\begin{array}{l}\text { 4-Pyridinone } \\
\text { impurity }\end{array}$ & $\begin{array}{l}\text { 1-(1H-benzimidazol-2-yl)-3-methyl } \\
\text {-4-oxo-1,4-dihydropyridine- } \\
\text { 2-carboxylic acid }\end{array}$ & & $\begin{array}{l}\text { Process } \\
\text { and } \\
\text { degradant }\end{array}$ \\
\hline $\begin{array}{l}\text { Rabeprazole } \\
\text { N-oxide }\end{array}$ & $\begin{array}{l}\text { 2-[[(1H-Benzo[d]imidazol-2-yl) } \\
\text { sulfinyl]methyl]-4- } \\
\text { (3-methoxypropoxy)-3- } \\
\text { methylpyridine 1-oxide }\end{array}$ & & $\begin{array}{l}\text { Process } \\
\text { Related } \\
\text { impurity }\end{array}$ \\
\hline $\begin{array}{l}\text { Rabeprazole } \\
\text { Methoxy analog }\end{array}$ & $\begin{array}{l}\text { 2-[[(4-Methoxy-3-methyl-2- } \\
\text { pyridyl) methyl] sulfinyl] } \\
\text { benzimidazole }\end{array}$ & & $\begin{array}{l}\text { Process } \\
\text { Related } \\
\text { impurity }\end{array}$ \\
\hline $\begin{array}{l}\text { Rabeprazole } \\
\text { Sulfone analog }\end{array}$ & $\begin{array}{l}\text { 2- }[\{(4-M e t h o x y \text { propoxy)-3- } \\
\text { methyl pyridine-2-yl\} methyl } \\
\text { sulphone]-1H-benzimidazole }\end{array}$ & & $\begin{array}{l}\text { Process } \\
\text { and } \\
\text { degradant }\end{array}$ \\
\hline $\begin{array}{l}\text { Rabeprazole } \\
\text { Chloroanalog }\end{array}$ & $\begin{array}{l}\text { 2-[[(4-Chloro-3-methyl-2-pyridyl) } \\
\text { methyl]sulfinyl] benzimidazole, } \\
\text { Sodium salt }\end{array}$ & & $\begin{array}{l}\text { Process } \\
\text { Related } \\
\text { impurity }\end{array}$ \\
\hline $\begin{array}{l}\text { Rabeprazole } \\
\text { Sulfideanalog }\end{array}$ & $\begin{array}{l}\text { 2- }[\{(4-m e t h o x y \text { propoxy }) \\
\text {-3-methyl-2-pyridine-2-yl }\} \\
\text { methyl thio } 1 \mathrm{H} \text {-benzimidazole }\end{array}$ & & $\begin{array}{l}\text { Raw Material } \\
\text { and Degradant } \\
\text { impurity }\end{array}$ \\
\hline
\end{tabular}




\section{MATERIALS AND METHODS}

The DEX $\bullet \mathrm{Na}$ and its six impurities viz. 4-pyridinine (A), sulfone analog (B), sulfideanalog $(C)$, $\mathrm{N}$-oxide (D), chloroanalog(E) and methoxy analog (G)(see Table 1) were synthesized and characterized in Emcure Pharmaceutical Limited, Analytical Research Centre Hinjawadi, Pune. Purified milli-Q water and analytical grade acetonitrile, methanol, di-potassium hydrogen phosphate as well as potassium hydrogen phosphate are used throughout The Waters Acquity UPLC (H Class) system with PDA/UV detector and Empower 2 software for data acquisition are used. All the instruments were calibrated during method development and validation.

The buffer is prepared by dissolving $1.74 \mathrm{~g}$ of di-potassium hydrogen phosphate anhydrous and $1.36 \mathrm{~g}$ of potassium di-hydrogen phosphate in purified water and diluted to $1000 \mathrm{ml}$. The homogeneous mixture of $990 \mathrm{ml}$ buffer and $10 \mathrm{ml}$ acetonitrile are used as a mobile phase- $\mathrm{A}$ while mobile phase $B$ is a mixture of $950 \mathrm{ml}$ methanol and $50 \mathrm{ml}$ acetonitrile. The mixture of $900 \mathrm{ml}$ of $0.01 \mathrm{~N}$ sodium hydroxide and $100 \mathrm{ml}$ methanol is used as a diluent for the sample and standard preparation. The $500 \mathrm{ppm}$ solutions of DEX $\cdot \mathrm{Na}$ both for system suitability test for peak identification and sample solution were prepared.

\section{Analytical Method development}

The UPLC methods usually require short time for analysis therefore solvent consumption and exposure is very less cost-effective method, results can obtain within short time. Therefore, proposed the UPLC technique for development of analytical method for related substances of $\mathrm{DEX} \cdot \mathrm{Na}$. The DEX・Na and its impurities are quite polar hence analytical method using reverse phase chromatography is development for their separation. Different combination of mobile phase parameters, $\mathrm{pH}$ and columns are considered during present RP-UPLC method. It is observed that, separations of all known and unknown impurities are very sensitive to aforementioned parameters. The DEX $\bullet \mathrm{Na}$ and its impurities show maxima near to $284 \mathrm{~nm}$ therefore, this wavelength is chosen for analyte detection during method development. The UPLC columns having $2.1 \mathrm{X} 100 \mathrm{~mm}$ dimensions and $1.9 \mu \mathrm{m}$ stationary phase particle size with different carbon load (C8 and C18) are used, where late eluting peaks and their broad peaks are observed. When Acquity BEH C4 column $(2.1 \mathrm{X} 100 \mathrm{~mm} 1.7 \mu \mathrm{m})$ is used the known and unknown impurities are eluted in 10 min. with sharp peak shape, however the chloroanalog impurity elute together with methoxy analog impurity. To separate the chloro and methoxy analogues impurities the carbon loading of Acquity BEH column is increased from C4 to C18. All known and unknown impurities are well resolved from each other and from analyte with proper peak shapes when Acquity BEH C18 (2.1 $\times 50 \mathrm{~mm} 1.7 \mu \mathrm{m}$ ) column is used. Among different column oven temperature $\left(30,35,40\right.$ and $\left.45^{\circ} \mathrm{C}\right)$ better chromatograms is observed at $40^{\circ} \mathrm{C}$. The other parameter such as sampling rate (5 points/second), injection volume $(3 \mu \mathrm{L})$ and flow rate $(0.45 \mathrm{ml} / \mathrm{min}$.) are set by performing different experiment.

The method is established by using gradient program with combination of phosphate buffer (mobile phase A) and mixture of organic solvents (mobile phase B).Initially the composition of mobile phase $A$ and $B$ in 77:23 ratios have been used, which is then gradually changed to $55: 45$ up to $0.80 \mathrm{~min}$. and maintain till 2.00 minutes. Then mobile phase ratio is slowly changed to $50: 50$ up to $3.50 \mathrm{~min}$. and to $20: 80$ up to $5.50 \mathrm{~min}$. which is maintained till 7.50 $\mathrm{min}$. Finally, composition is abruptly brought to initial values of $77: 23$ up to $7.60 \mathrm{~min}$. and maintained till 10 minute.

\section{RESULTS AND DISCUSSION}

The analytical method validation is carried out as per ICH guideline. ${ }^{13,14}$ All parameters in the method validation are discussed below.

\section{Specificity}

Specificity is the ability of the method to measure the analyte response in the presence of its impurities. This can be done by spiking known impurities with its limit levels and demonstrate the results are unaffected by presence of known impurities. Selectivity chromatogram for blank, mix impurities standard, unspiked and spiked test are shown in Fig. 1. Blank run does not show any interfering peak at the retention time of DEX $\bullet \mathrm{Na}$ and its related impurities peak. The peak due to $\mathrm{DEX} \cdot \mathrm{Na}$ is well resolved from known impurities. 
The selectivity data for spiked test preparations are given in Table 2. Peak purity angle of DEX•Na and its known impurities are below peak purity threshold for all individual solutions of impurities, standard preparations, unspiked and spiked test preparations, thus these peaks are homogeneous and pure. The $\%$ relative standard deviation of six replicates of standard preparation with mixture of impurities (A-E and $\mathrm{G}$ ) and $\mathrm{DEX} \cdot \mathrm{Na}$ at limit level are $0.26,0.37,0.22$, $0.51,0.50,0.15$ and $0.59 \%$, respectively. Tailing factor and theoretical plates in system suitability preparation of DEX $\cdot \mathrm{Na}$ are 1.14 and 19347 , respectively. The resolution between $\mathrm{DEX} \cdot \mathrm{Na}$ and closest eluting chloro analog is 2.69 the resolution values for all other impurities are even larger.

Table 2: Selectivity data of spiked test preparation for DEX•Na

\begin{tabular}{lccccccc}
\hline $\begin{array}{l}\text { Peak } \\
\text { name }\end{array}$ & $\begin{array}{c}\text { Peak(Impurity) } \\
\text { name }\end{array}$ & $\begin{array}{c}\text { RT } \\
(\mathrm{min})\end{array}$ & $\begin{array}{c}\text { RT } \\
\text { Ratio }\end{array}$ & Resolution & $\begin{array}{c}\text { Purity } \\
\text { Angle }\end{array}$ & $\begin{array}{c}\text { Purity } \\
\text { Threshold }\end{array}$ & $\begin{array}{c}\text { Peak } \\
\text { Purity }\end{array}$ \\
\hline A & 4-Pyridinone & 0.553 & 0.18 & NA & 1.462 & 1.572 & Pass \\
B & N-oxide & 1.996 & 0.64 & 27.05 & 0.180 & 1.393 & Pass \\
C & Methoxy Analog & 2.286 & 0.73 & 4.70 & 0.066 & 1.147 & Pass \\
D & Sulfone Analog & 2.630 & 0.84 & 4.77 & 0.092 & 1.466 & Pass \\
E & Chloro Analog & 2.883 & 0.92 & 3.04 & 0.196 & 2.623 & Pass \\
F & DEX $• N a$ & 3.139 & 1.00 & 2.69 & 0.419 & 2.325 & Pass \\
G & Sulfide Analog & 4.986 & 1.59 & 24.62 & 0.272 & 1.397 & Pass \\
\hline
\end{tabular}

\section{Limit of detection and Limit of quantitation}

The limit of detection (LOD) is the point at which a measured value is larger than the uncertainty associated with it. It is the lowest concentration of analyte in a sample that can be detected, but not necessarily quantified. The limit of quantitation (LOQ) of an individual analytical procedure is the lowest amount of analyte in a sample which can be quantitatively determined with suitable precision and accuracy. The limit of detection and quantitation are determined from signal-to-noise ratios being $3: 1$ and $10: 1$, respectively and reported in the Table 3 . The observed LOD and LOQ are in between 0.0015 to $0.0025 \%$ and 0.0046 to $0.0076 \%$, respectively. The reported LOD and LOQ values are lower than the earlier methods in literature. ${ }^{11,12}$

Table 3: Limit of detection and quantitation data of DEX•Na and its related impurities

\begin{tabular}{lccccc}
\hline $\begin{array}{l}\text { Peak } \\
\text { Name }\end{array}$ & $\begin{array}{c}\text { Peak } \\
\text { name }\end{array}$ & LOD in \% & $\begin{array}{r}\text { LOD in ppm } \\
\text { w. r. t. test Conc.500 ppm }\end{array}$ & $\begin{array}{c}\text { LOQ in \% } \\
\text { LOQ in ppm }\end{array}$ \\
\hline A & 4-Pyridinone Impurity & 0.0024 & 0.012 & 0.0074 & 0.037 \\
B & N-oxide & 0.0022 & 0.011 & 0.0068 & 0.034 \\
C & Methoxy Analog & 0.0024 & 0.012 & 0.0074 & 0.037 \\
D & Sulfone Analog & 0.0022 & 0.011 & 0.0068 & 0.034 \\
E & Chloro Analog & 0.0022 & 0.011 & 0.0068 & 0.034 \\
F & DEX•Na & 0.0015 & 0.0075 & 0.0046 & 0.023 \\
G & Sulfide Analog & 0.0025 & 0.0125 & 0.0076 & 0.038 \\
\hline
\end{tabular}

\section{Linearity and Range}

Linearity of method is the measure of the proximity of the straight line obtained from a calibration plot of response versus concentration. It is obtained by performing the experiments using different concentrations of the DEX $\bullet \mathrm{Na}$ and its known impurities. Thus, the linearity of present UPLC method is determined from LOQ level to $150 \%$ of specification limit concentrations $(0.50 \mathrm{ppm}$ for DEX $\bullet N a$ and 0.75 ppm for each impurity). The typical chromatograms of blank, overlay linearity levels are shown in Fig. 2. The peak area versus concentration data was treated by least squares linear regression analysis. All observed value (in Table 4) and graph plotted (see Fig. 3) indicates that this method is linear for given range. The LOQ obtained from this 
data is precise with the values in the Table 3 . The straight-line nature of graph shows that method is linear in the range from LOQ to $150 \%$ of known impurities and DEX•Na. The linearity was plotted in

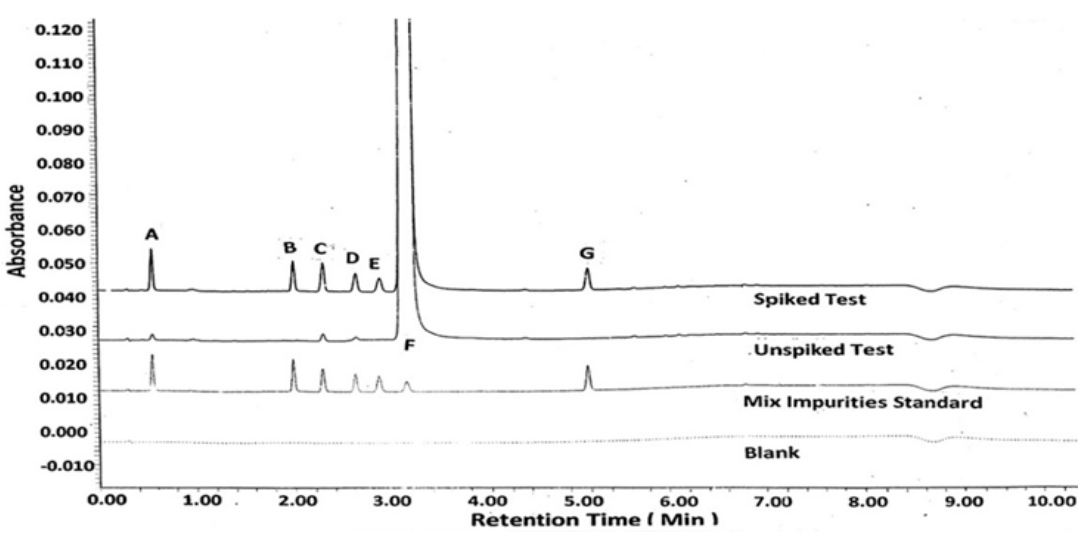

Fig. 1. Selectivity chromatogram for blank, mix impurities standard, unspiked and spiked test.

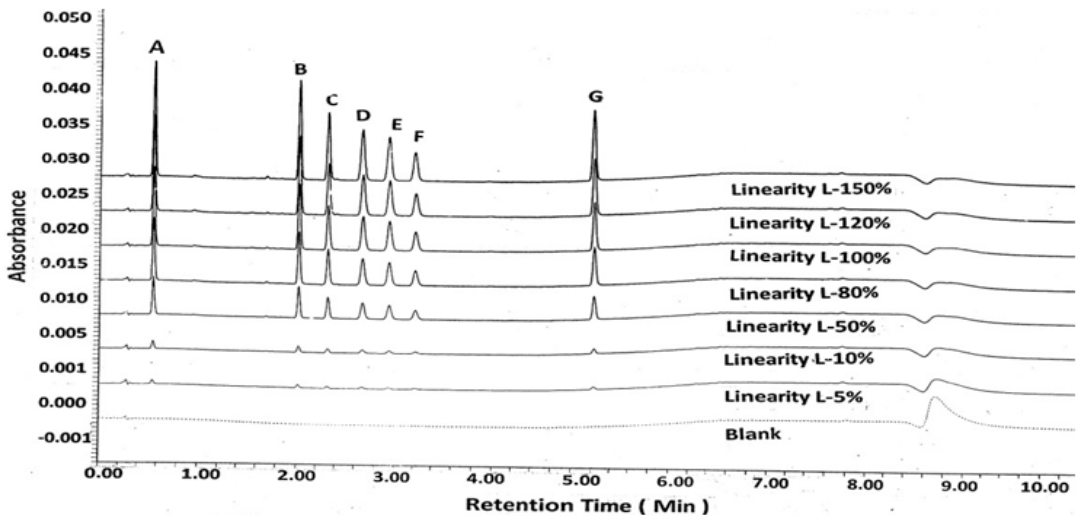

Fig. 2. Linearity levels chromatograms blank, LOQ (5\%) to $150 \%$ level concentration
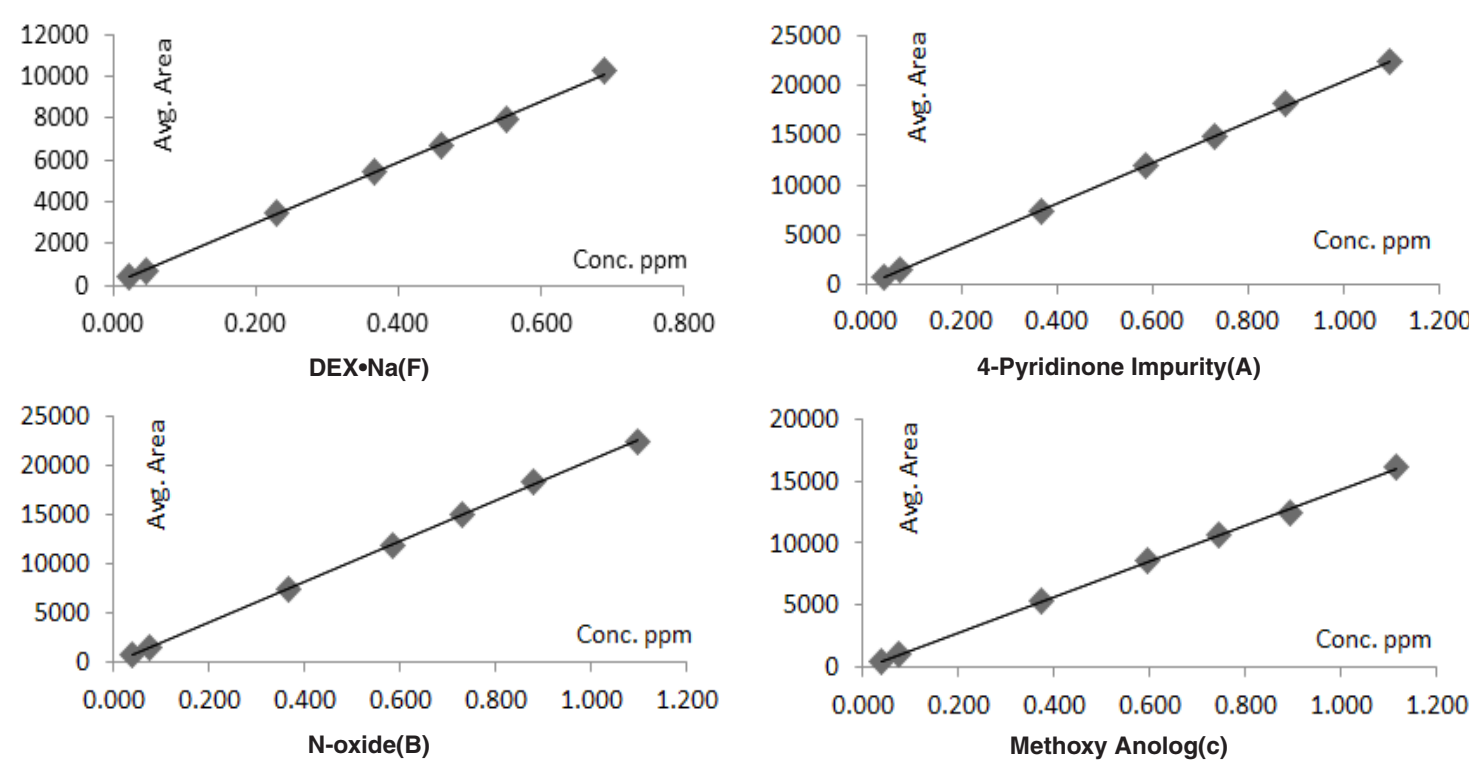

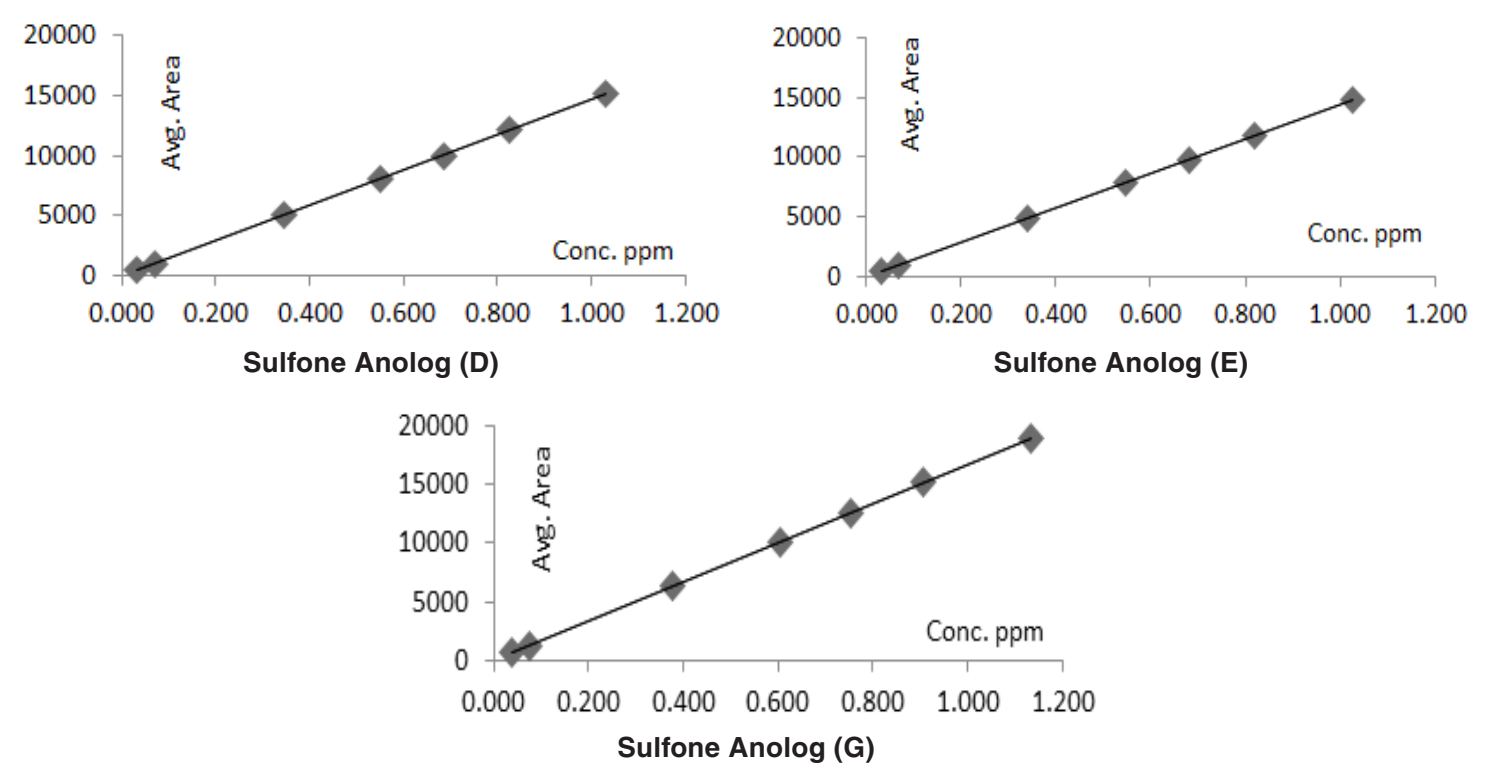

Fig. 3. Linearity Graphs of DEX•Na and its (A-E and $G$ ) impurities with concentration range from the $L O Q-150 \%$ of concentration

Table 4: Linearity data for related impurities of DEX•Na from LOQ $-150 \%$ concentration range Impurities

\begin{tabular}{lcccccc}
\hline & A & B & C & D & E & G \\
\hline Correlation Coefficient & 0.9999 & 0.9999 & 0.9997 & 0.9999 & 0.9999 & 0.9999 \\
Slope & 20531 & 19327 & 14284 & 14775 & 14407 & 16662 \\
Intercept & -49.70 & -51.36 & -19.37 & -51.69 & -61.36 & 5.06 \\
\hline
\end{tabular}

\section{Precision}

System precision is performed with six replicates of standard solution of DEX $\bullet \mathrm{Na}$ in presence of impurities. System suitability criteria such as tailing factor, theoretical plates, \%RSD and resolution are calculated. \%RSD results in system precision study for impurities (A-E and G) and DEX $\cdot \mathrm{Na}$ are $0.22,0.21,0.19,0.44,0.52$, 2.91 and $0.14 \%$, respectively. Tailing factor and theoretical plates in system suitability preparation of DEX $\cdot \mathrm{Na}$ are 1.31 and 19058 , respectively. The method precision is performed by injecting six replicate of sample solutions after spiking of impurities at specification limit level. While an intermediate precision is evaluated by changing analyst, instrument and column on different day. For calculation of the \%RSD for each method and intermediate precisions, six replicates of spiked impurities are considered. The comparison data of method precision and intermediate precision are presented in Table 5. Overall \%RSD of twelve samples i.e. six from method precision and six from intermediate precision of impurities (A-E and $G$ ) as well as total Impurities are 2.00, 2.41, 3.89, 3.31, $3.13,2.07$ and $2.91 \%$ respectively. The resolution between peak of DEX $\cdot \mathrm{Na}$ and chloro analog is 02.91 .

\section{Accuracy}

Accuracy can also be described as the closeness of agreement between the value that is adopted, either as a conventional, true, or accepted reference value, and the value found. Accuracy study of all known impurities is carried out in triplicate at LOQ level, 50, 100 and $150 \%$ concentration. Observed \% recoveries of all six known impurities are between 95.07 to $102.73 \%$. Recovery data is given in Table 6 and typical chromatograms of different recovery levels are shown in Figure 4.

\section{Robustness}

The robustness of analytical method is determined by purposeful alteration of experimental conditions such as flow rate (by $\pm 10 \%$ ) and column 
oven temperature $\left( \pm 5^{\circ} \mathrm{C}\right)$. Actual flow rate of $0.45 \mathrm{ml} / \mathrm{min}$. is altered to $0.40 \mathrm{ml} / \mathrm{min}$. and $0.50 \mathrm{ml} / \mathrm{min}$. Similarly, the column oven temperature is changed from $40^{\circ} \mathrm{C}$ in original method to 35 and $45^{\circ} \mathrm{C}$. In all above cases the retention times are varied by \pm 0.12 to \pm 0.6 min. compared to actual retention times. System suitability parameter such as tailing factor, theoretical plates, resolution and \%RSD are range from 1.26-1.31, 15730-20735,2.89-3.04 and $0.05-4.04$, respectively. The relative \% impurities with reference to the corresponding values in method precision obtained for the altered method parameter are given in Table 7. In all deliberate varied chromatographic conditions (flow rate, column oven temperature and column) the values of system suitability criteria are almost similar to that of method precision. The \% deviation for these values compared to one in method precession are below $9.00 \%$, which is within the limit $(20 \%)$ prescribed by $\mathrm{ICH}$ guidelines. ${ }^{13}$

Table 5: Comparative data of method precision and intermediate precision in spiked test

\begin{tabular}{|c|c|c|c|c|c|c|c|c|c|c|c|c|c|c|}
\hline \multirow[t]{2}{*}{ Test } & \multicolumn{2}{|l|}{$\% A$} & \multicolumn{2}{|l|}{$\% B$} & \multicolumn{2}{|l|}{$\% \mathrm{C}$} & \multicolumn{2}{|l|}{$\% D$} & \multicolumn{2}{|l|}{$\% \mathrm{E}$} & \multirow{2}{*}{$\begin{array}{c}\% \mathrm{G} \\
\mathrm{MP}\end{array}$} & \multicolumn{3}{|c|}{$\%$ Total impurities } \\
\hline & MP & IP & MP & IP & MP & IP & MP & IP & MP & IP & & IP & MP & IP \\
\hline Spiked test 1 & 0.146 & 0.145 & 0.136 & 0.139 & 0.147 & 0.152 & 0.135 & 0.139 & 0.134 & 0.136 & 0.151 & 0.153 & 0.881 & 0.904 \\
\hline Spiked test 2 & 0.142 & 0.147 & 0.133 & 0.140 & 0.143 & 0.155 & 0.132 & 0.141 & 0.131 & 0.138 & 0.147 & 0.153 & 0.860 & 0.913 \\
\hline Spiked test 3 & 0.146 & 0.146 & 0.137 & 0.140 & 0.148 & 0.155 & 0.135 & 0.140 & 0.134 & 0.137 & 0.151 & 0.155 & 0.884 & 0.911 \\
\hline Spiked test 4 & 0.143 & 0.147 & 0.134 & 0.139 & 0.144 & 0.152 & 0.133 & 0.140 & 0.132 & 0.136 & 0.149 & 0.153 & 0.867 & 0.905 \\
\hline Spiked test 5 & 0.137 & 0.147 & 0.129 & 0.139 & 0.137 & 0.155 & 0.127 & 0.141 & 0.123 & 0.138 & 0.143 & 0.154 & 0.826 & 0.907 \\
\hline Spiked test 6 & 0.143 & 0.145 & 0.135 & 0.138 & 0.144 & 0.153 & 0.132 & 0.138 & 0.131 & 0.136 & 0.148 & 0.153 & 0.864 & 0.902 \\
\hline Mean $(n=6)$ & 0.143 & 0.146 & 0.134 & 0.139 & 0.144 & 0.154 & 0.132 & 0.140 & 0.131 & 0.137 & 0.148 & 0.154 & 0.864 & 0.907 \\
\hline$S D(n=6)$ & 0.003 & 0.001 & 0.003 & 0.001 & 0.004 & 0.002 & 0.003 & 0.001 & 0.004 & 0.001 & 0.003 & 0.001 & 0.021 & 0.006 \\
\hline$\% \operatorname{RSD}(\mathrm{n}=6)$ & 2.31 & 0.68 & 2.09 & 0.58 & 2.71 & 0.97 & 2.20 & 0.86 & 3.13 & 0.73 & 2.03 & 0.52 & 2.41 & 0.71 \\
\hline Mean $(n=12)$ & & 0.145 & & 0.137 & & 0.149 & & 0.136 & & 0.134 & & 0.151 & & 0.885 \\
\hline $\mathrm{SD}(\mathrm{n}=12)$ & & 0.003 & & 0.003 & & 0.006 & & 0.005 & & 0.004 & & 0.004 & & 0.027 \\
\hline$\% R S D(n=12)$ & & 2.00 & & 2.41 & & 3.89 & & 3.31 & & 3.13 & & 2.32 & & 3.03 \\
\hline
\end{tabular}

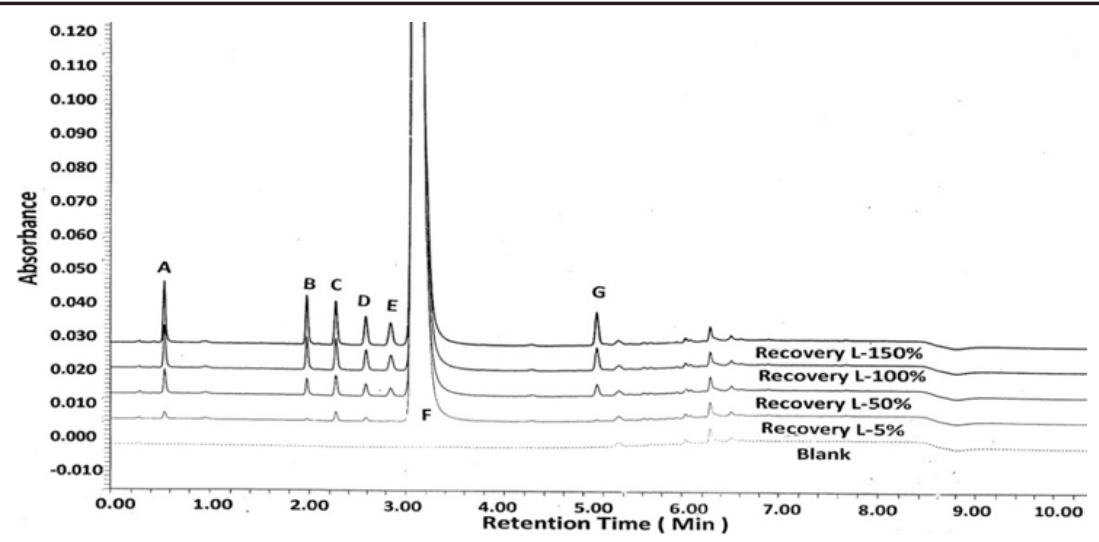

Fig. 4: Chromatogram for blank, recovery levels from LOQ to $150 \%$ concentration

Table 6: \% Recovery data of related impurities of DEX•Na impurities

\begin{tabular}{ccccc}
\hline Impurities & LOQ Level $(n=3)$ & $50 \%$ Level $(n=3)$ & $100 \%$ Level $(n=3)$ & $150 \%$ Level $(n=3)$ \\
\hline A & $100.00 \pm 0.00$ & $99.53 \pm 0.81$ & $100.46 \pm 0.40$ & $99.69 \pm 0.27$ \\
B & $95.07 \pm 3.69$ & $100.00 \pm 0.00$ & $94.79 \pm 0.67$ & $99.50 \pm 0.00$ \\
C & $101.79 \pm 6.84$ & $98.15 \pm 0.81$ & $99.77 \pm 0.40$ & $99.69 \pm 0.27$ \\
D & $99.02 \pm 6.62$ & $100.00 \pm 0.00$ & $99.26 \pm 0.01$ & $99.34 \pm 0.29$ \\
E & $101.49 \pm 2.99$ & $99.49 \pm 0.88$ & $98.26 \pm 0.41$ & $99.00 \pm 0.01$ \\
G & $100.91 \pm 3.38$ & $102.73 \pm 0.02$ & $100.90 \pm 0.38$ & $101.35 \pm 0.00$ \\
\hline
\end{tabular}


Table 7: Comparison data of method precision and robustness study of spiked impurities

\% Impurities relative to $\mathrm{MP}^{*}$

\begin{tabular}{lccccccc}
\hline Parameter & Total & A & B & C & D & E & G \\
\hline MP & 0 & 0 & 0 & 0 & 0 & 0 & 0 \\
-0.864 & -0.143 & -0.134 & -0.144 & -0.132 & -0.131 & -0.148 & \\
Temp. $\left(35^{\circ} \mathrm{C}\right)$ & 0.016 & 0.005 & 0.001 & 0.002 & 0.004 & 0.005 & 0.001 \\
Temp. $\left(45^{\circ} \mathrm{C}\right)$ & 0.015 & 0.004 & 0.001 & 0.003 & 0.004 & 0.002 & 0.001 \\
Flow $(0.40 \mathrm{ml} / \mathrm{min})$. & 0.006 & 0.005 & 0.001 & 0.002 & 0.004 & 0.002 & 0 \\
Flow $(0.50 \mathrm{ml} / \mathrm{min})$. & 0.007 & 0.005 & 0 & 0.002 & 0.005 & 0.002 & 0.014 \\
\hline
\end{tabular}

* The \% impurity values for MP are given in parenthesis.

\section{Solution Stability}

The solution stability of standard as well as sample solutions and solutions used for system suitability test is performed on 24 and $48 \mathrm{~h}$. at the controlled room temperature $\left(25^{\circ} \mathrm{C}\right)$. The \% recovery for impurities (A-E and $G$ ) in standard solutions are 99.17(101.57), 98.68 (99.48),99.10 (99.13),99.02 (100.03), 99.86 (100.35), 99.11 (100.58) and 101.55 (101.77) \% for 24 (48) h, respectively. Cumulative \% RSD of concentration of these impurities in \% for is $0.42,0.43,0.00,1.24,0.44$, and $0.78 \%$. Also, there is insignificant change in tailing factor, theoretical plates and resolution up to $48 \mathrm{~h}$. This indicates that the solutions are quite stable at least up to 48 hours.

\section{Mobile phase stability}

The mobile phase stability at the controlled room temperature is performed on 24 and $48 \mathrm{~h}$. Until $48 \mathrm{~h}$ for both $\mathrm{A}$ and $\mathrm{B}$ mobile phases the appearance is clear, and haziness is not observed. The observed $\%$ RSD of all the (A-E and $G$ ) impurities and DEX•Na in standard solutions on $48 \mathrm{~h}$ are $0.38,0.60,0.79,0$. $28,0.75,1.20$ and $0.63 \%$, respectively. Furthermore, system suitability parameters such as tailing factor, theoretical plates and resolution are comparable with initial data. Therefore, mobile phase is stable up to 48 $\mathrm{h}$ when stored at the controlled room temperature.

\section{Forced degradation study}

Forced degradation study gives a measure of specificity and it helps in selection of stabilityindicating analytical procedures. The \% degradation of analyte is determined by comparing chromatogram of untreated sample and samples maintained under (thermal, photolytic, humidity, aqueous, acidic, basic and oxidative) stress conditions. The degradation data of DEX $• \mathrm{Na}$ under such conditions are shown in Table 8. In thermal degradation sample was heated at $60^{\circ} \mathrm{C}$ for $24 \mathrm{~h}$, humidity degradation carried out at $40^{\circ} \mathrm{C}$ with $75 \%$ relative humidity for $24 \mathrm{~h}$ and in photolytic degradation sample solution is treated with light energy of $1.2 \times 106$ lux h using near-UV 200 $\mathrm{Wh} / \mathrm{m}^{2}$ source. The colour of DEX $\cdot \mathrm{Na}$ solid sample is changed from pale yellow to yellow due to these heat, humidity and photolytic condition, however the $\%$ impurities and peak area of the DEX $\cdot N a$ remained constant without any degradant peak. This indicates that DEX $\bullet \mathrm{Na}$ molecule is stable for heat, humidity and photolytic stress conditions. The solution- $A$ is prepared by dissolving $50.0 \mathrm{mg}$ of $\mathrm{DEX} \cdot \mathrm{Na}$ in 5.0 $\mathrm{ml}$ of diluent, which is then exposed to the desired stress condition. The solution is then neutralized, and final volume is adjusted using diluent to 100 $\mathrm{ml}$ in volumetric flask. In acid degradation study, DEX $\bullet \mathrm{Na}$ solution is exposed to $3.5 \mathrm{ml}$ of $0.02 \mathrm{~N} \mathrm{HCl}$ at room temperature for $10 \mathrm{~min}$. and then neutralized with $0.02 \mathrm{~N} \mathrm{NaOH}$. In alkali degradation, solution-A of DEX $\bullet \mathrm{Na}$ is exposed to $5.0 \mathrm{ml}$ of $0.5 \mathrm{~N} \mathrm{NaOH}$ at $60^{\circ} \mathrm{C}$ for $4 \mathrm{~h}$ in oil bath. After $4 \mathrm{~h}$ solution is cooled and neutralized with $0.5 \mathrm{~N} \mathrm{HCl}$. In oxidation degradation, solution- $A$ is exposed to $2.0 \mathrm{ml} 30 \% \mathrm{H}_{2} \mathrm{O}_{2}$ at room temp for $20 \mathrm{~min}$. Final volume of solution-A after each stress treatment is made up to $100 \mathrm{ml}$ in volumetric flask and chromatograms are recorded (see Fig 5-7). All degradant impurities are well separated from DEX $\cdot N a$ and its known impurities. Overall 11.90, 0.72 and $5.30 \%$ degradation (see Table 8 ) are observed for acid, basic and oxidative stress, respectively. In acid degradation the sulphide analogue impurity $(G)$ 
is the major degradant, while in oxidative degradation sulfone analog (D)as major degradant. Insignificant degradation of $\mathrm{DEX} \bullet \mathrm{Na}$ in alkaline condition renders its stability in basic medium.

Table 8: The stress conditions with \% degradation of DEX•Na

\begin{tabular}{|c|c|c|c|c|c|c|}
\hline ID & $\begin{array}{l}\text { Form of } \\
\text { sample }\end{array}$ & $\begin{array}{l}\text { Degradation } \\
\text { Condition }\end{array}$ & $\begin{array}{l}\text { Purity } \\
\text { Angle }\end{array}$ & $\begin{array}{c}\text { Purity } \\
\text { Threshold } \\
\text { (unit) }\end{array}$ & $\begin{array}{l}\text { Peak } \\
\text { purity } \\
\text { (unit) }\end{array}$ & $\begin{array}{c}\% \\
\text { Degradation } \\
\text { (unit) }\end{array}$ \\
\hline $\begin{array}{l}\text { Untreated } \\
\text { Sample }\end{array}$ & Solid & - & 0.040 & 0.253 & Pass & -- \\
\hline Photolytic & Solid & $\begin{array}{l}\text { Light energy of } 1.2 \text { million lux } \mathrm{h} \text {. } \\
\text { and near UV } 200 \text {-watt } \mathrm{h} / \mathrm{m}^{2}\end{array}$ & 0.043 & 0.255 & Pass & -- \\
\hline Humidity & Solid & $75 \% \mathrm{RH}$ at $40^{\circ} \mathrm{C}$ for $24 \mathrm{~h}$ & 0.041 & 0.250 & Pass & -- \\
\hline Heat & Solid & $24 \mathrm{~h}$ at $60^{\circ} \mathrm{C}$ & 0.038 & 0.254 & Pass & -- \\
\hline Aqueous & Solution & $5 \mathrm{ml}$ water at room temp. for $24 \mathrm{~h}$ & 0.041 & 0.254 & Pass & -- \\
\hline Peroxide & Solution & $2 \mathrm{ml} 30 \% \mathrm{H}_{2} \mathrm{O}_{2} \mathrm{Kept}$ at room temp for $20 \mathrm{~min}$. & 0.036 & 0.242 & Pass & 5.34 \\
\hline Acid & Solution & $3.5 \mathrm{ml}$ of $0.02 \mathrm{~N} \mathrm{HCl}$ at room temp for $10 \mathrm{~min}$. & 0.046 & 0.252 & Pass & 11.92 \\
\hline Alkali & Solution & $\begin{array}{l}5 \mathrm{ml} \text { of } 0.5 \mathrm{~N} \mathrm{NaOH} \text {, heat the } \\
\text { solution at } 60^{\circ} \mathrm{C} \text { on oil bath for } 4 \mathrm{~h}\end{array}$ & 0.033 & 0.253 & Pass & 0.72 \\
\hline
\end{tabular}

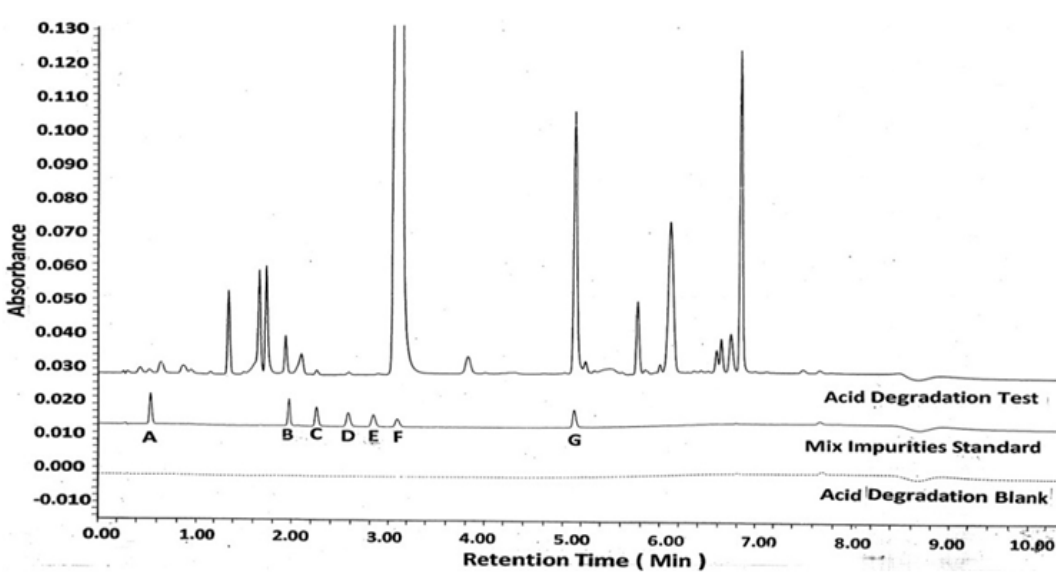

Fig. 5. Chromatogram for the acid degradation studies of DEX•Na

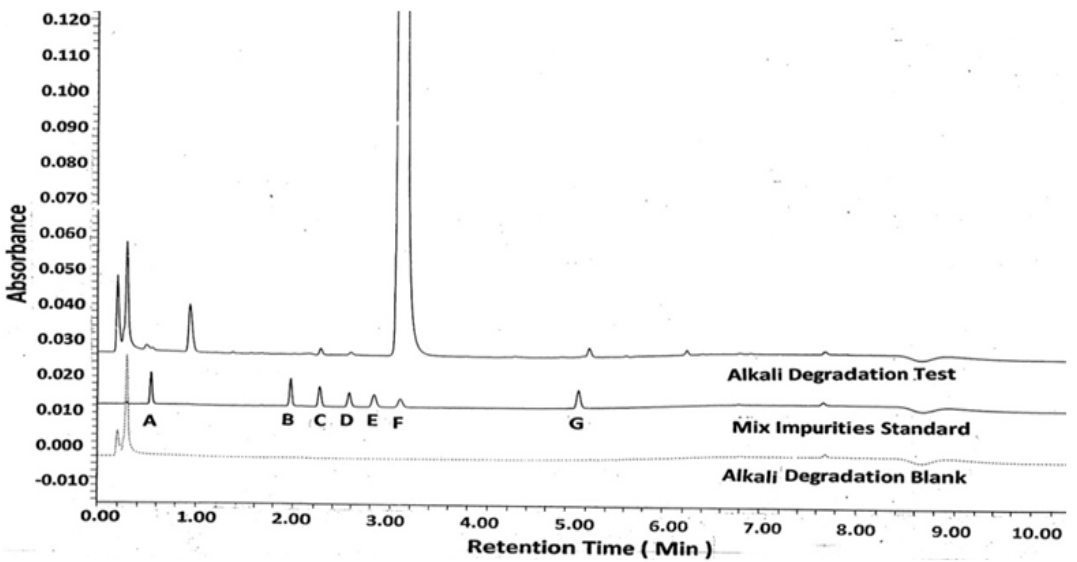

Fig. 6. Chromatogram for the alkali degradation studies of DEX•Na 


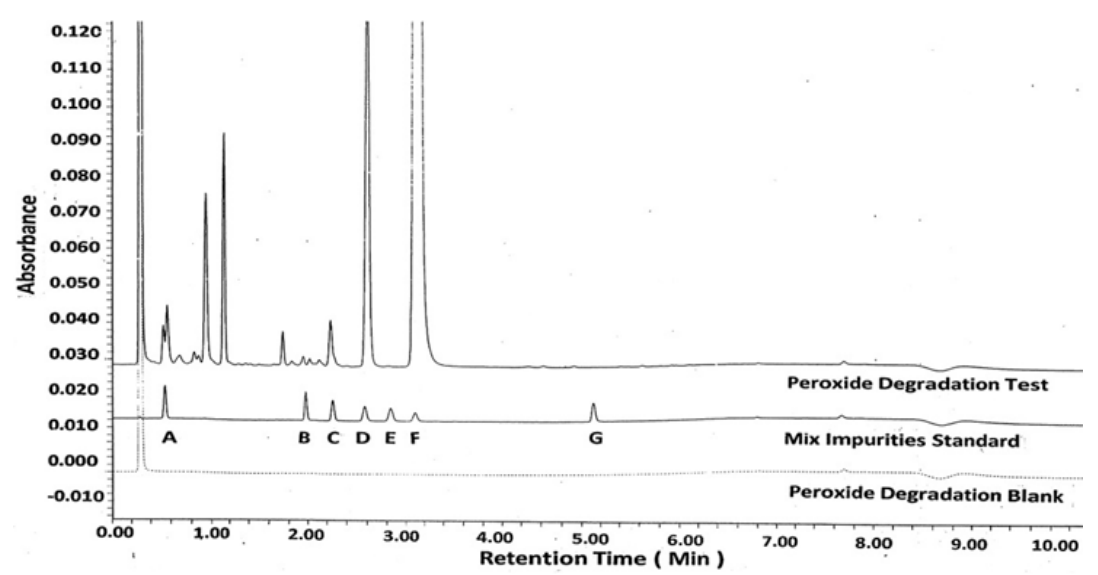

Fig. 7. Chromatogram for the peroxide degradation studies of DEX•Na

CONCLUSION

Dexrabeprazole sodium $(\mathrm{DEX} \cdot \mathrm{Na})$ is an active pharmaceutical ingredient and used as proton pump inhibitor. A RP-UPLC method is developed for determination of related impurities in $\mathrm{DEX} \bullet \mathrm{Na}$ and it is validated using $\mathrm{ICH}$ guideline. This RP-UPLC method is developed using BEH C18 (2.1 $X 50 \mathrm{~mm}) 1.7 \mu \mathrm{m}$ column and gradient program for mobile phase. Mobile phase A contains $99 \%$ buffer of potassium di-hydrogen phosphate and di-potassium hydrogen phosphate with $\sim 7.0 \mathrm{pH}$ and $1 \%$ acetonitrile, whereas mobile phase $B$ is the methanol and acetonitrile in $95: 5$ ratio. The $0.45 \mathrm{ml} /$ min. total flow rate, $3.0 \mu \mathrm{l}$ injection volume, $40^{\circ} \mathrm{C}$ column oven temperature and $284 \mathrm{~nm}$ detection wavelength are used. The sampling rate is 5 points per second. Run time of the method is $10 \mathrm{~min}$. which is much faster compared to the $85-90 \mathrm{~min}$. in reported methods. The DEX•Na peak is well separated from its known (A-E and $G$ ) and unknown impurities. Linearity and accuracy study of impurities was performed in the range of LOQ to $150 \%$ level with respect to specification concentration limit. Solution and mobile phase are stable up to $48 \mathrm{~h}$ and the method is robust also. The forced degradation study reveals that the DEX•Na is stable in the alkaline medium, while it significantly degrades in acidic and oxidative stress condition mainly to sulfide and sulfone analogues, respectively. The present RP-UPLC method is not only precise, accurate, linear and rapid but also qualifies all the stability and robustness criteria. This may be used for routine quality control analysis.

\section{ACKNOWLEDGEMENT}

The Santosh Khadangale and Vitthal Dhalape thank to Dr. Mukund Gurjar, Emcure Pharmaceuticals Limited, Analytical Research Centre, Hinjawadi, Pune for his support, encouragement and permitting this work to communicate for publication.

\section{REFERENCES}

1. Richardson, P.; Hawkey C.; Stack W. Drugs., 1998, 56, 307-35.

2. Feret B.; Quercia R.; Cappa J. Formulary., 1999, 34,313-23.

3. Reilly J.P.;Am. J. Health. Syst. Pharm., 1999, 56, S11-7.

4. Bodhankar S.L.; Jain B.B.; Ahire B.P.; Daude R.B.; Shitole P.P. Indian.J. Pharmacol., 2006, 38(5), 357-58

5. Barth J.; Hahne W. Aliment. Pharmacol. Ther., 2002, 16, 31-33.

6. Kommanaboyina B,; Rhodes C.T. Drug. Dev. Ind. Pharm., 1999, 25, 857-868.

7. Cassia V.G.; Norma S.N.; Martin S.; Elfrides E.
S. S. J. Pharm. Biomed. Anal., 2008, 46, 88-93.

8. Mathew M.; Das Gupta V.; Bailey R.E. Drug. Dev. Ind.Pharm., 1995, 21, 965-971.

9. Radi A. Microchem. J., 2002, 73, 349-354.

10. Qaisi A.; Tutunji M.; Tutunji L. J. Pharm. Sci., 2006, 95, 384-391.

11. Navneet K.; Dhanaraj S. Sci. Pharm., 2013, 8, 697-711

12. Raghavaraju T.V.; Raja kumar S.;Mrutyunjaya Rao I.; Someswara Rao N. Asian. J. Pharm. Clin., 2013, 6, 43-51.

13. ICH. Guideline., 2005, Q2 (R1).

14. ICH. Guideline., 2003, Q1A (R2). 